DOI: $10.1515 / \mathrm{rrlm}-2016-0039$

\title{
Comparison of four chromatographic methods used for measurement of glycated hemoglobin
}

\section{Compararea a patru metode cromatografice utilizate pentru determinarea hemoglobinei glicozilate}

\author{
Enikő Nemes-Nagy ${ }^{1}$, Zita Fazakas ${ }^{1}$, Victor Balogh-Sămărghițan ${ }^{1}$, Zsuzsánna \\ Simon-Szabó ${ }^{2}$, Lóránd Dénes ${ }^{3}$, Cosmina Cristina Uzun ${ }^{1}$, Márta Andrea Fodor ${ }^{4}$, \\ Mariana Cornelia Tilinca ${ }^{5, *}$, Deborah Reid ${ }^{6}$, Trefor Higgins ${ }^{6,7}$ \\ ${ }^{1}$ Department of Biochemistry and Chemistry of Environmental Factors, University of Medicine and \\ Pharmacy, Tîrgu Mureș, Romania, ${ }^{2}$ PhD student, University of Medicine and Pharmacy, Tîrgu Mureș, \\ Romania ${ }^{3}$ Department of Anatomy and Embriology, University of Medicine and Pharmacy, Tîrgu Mureş, \\ Romania, ${ }^{4}$ Department of Clinical Laboratory, University of Medicine and Pharmacy, Tîrgu Mureş, \\ Romania, ${ }^{5}$ Cellular and Molecular Biology Department, University of Medicine and Pharmacy, Tîrgu Mureş, \\ Romania, ${ }^{6}$ Clinical Chemistry Department, Dynalifedx Diagnostic Laboratory, Edmonton, Canada, \\ ${ }^{7}$ Clinical Professor of Laboratory Medicine, University of Alberta, Edmonton, Canada
}

\begin{abstract}
This parameter's results accuracy has a special importance in the management of diabetic patients since targets for optimal glycemic control are established using HbAlc values. Several error sources can influence the obtained value, some of them can be counteracted (ex. pipetting errors, storage), and others should be taken into consideration at the interpretation of the result (ex. presence of hemoglobin variants). The aim of this study was to compare four chromatographic methods regarding the costs and the influence of certain error sources on the accuracy of the result. Materials and methods: Samples and controls were analyzed using Variant I, Micromat II and In2it (Bio-Rad) systems, and the BIOMIDI reagent kit for HbAlc measurement. Results: Positive correlation could be observed comparing the results obtained using different methods, except the patients presenting elevated HbF. Pipetting errors modify the results up to 5\% in case of Variant I, and up to $10 \%$ in case of Micromat II in the tested range. One day of improper storage at room temperature causes $3 \%$ deviation from the actual value using the Variant I analyzer and 5\% in case of Micromat II and In2it equipment. As a conclusion, depending on the number of samples, automated chromatographic analyzers are the most appropriate equipments for the determination of HbAlc.
\end{abstract}

Keywords: glycated hemoglobin; high pressure liquid chromatography; hemoglobin variants; method comparison; error sources.

* Corresponding author: Mariana Cornelia Tilinca, Cellular and Molecular Biology Department, University of Medicine and Pharmacy, Gh. Marinescu Street, 38, Tîrgu Mureş, Romania, e-mail: mariana.tilinca@umftgm.ro 


\section{Rezumat}

Pentru dozarea hemoglobinei glicozilate (HbAlc) sunt folosite diverse metode. Acuratețea rezultatelor la acest parametru are o importanță specială în monitorizarea pacienților diabetici, deoarece valorile țintă pentru controlul glicemic normal sunt stablilite pe baza valorilor HbAlc. Mai multe surse de eroare pot influența valoarea obținută, unele dintre ele pot fi evitate (de exemplu erorile de pipetare și păstrare), altele trebuie luate în considerare la interpretarea rezultatelor (cum ar fi prezența hemoglobinopatiilor). Scopul studiului nostru a fost compararea a patru metode cromatografice cu privire la costuri și influența diferitelor surse de eroare asupra acurateții rezultatelor. Material și metode: Probele și controalele au fost analizate folosind analizoarele Variant I, Micromat II și In2it (Bio-Rad), respectiv kitul de reactivi BIOMIDI pentru dozarea HbAlc. Rezultate: S-a putut observa o corelație bună comparând rezultatele obținute prin aceste metode, cu excepția pacienților prezentând HbF crescută. Erorile de pipetare modifică rezultatele până la 5\% în cazul aparatului Variant I și până la $10 \%$ în cazul sistemului Micromat II în intervalul testat. O zi de păstrare neadecvată la temperatura camerei cauzează o deviere de 3\% de la valoarea actuală folosind analizorul Variant I și 5\% in cazul aparatelor Micromat II și In2it. Putem concluziona că depinzând de numărul probelor, analizoarele automate bazate pe cromatografie sunt cele mai adecvate echipamente pentru dozarea HbAlc.

Cuvinte cheie: hemoglobina glicozilată; cromatografie lichidă de înaltă presiune; hemoglobinopatii; compararea metodelor; surse de eroare.

Received: $21^{\text {th }}$ February 2016; Accepted: 10 ${ }^{\text {th }}$ October 2016; Published: 09 ${ }^{\text {th }}$ November 2016.

\section{Introduction}

HbA1c is the most important parameter for the evaluation of glycemic control in diabetes and the grounds for establishing a treatment strategy. Its value reflects the past 3-4 months' average blood glucose level. HbA1c is formed through a non-enzymatic glycation pathway by the exposure of hemoglobin to plasma glucose.

Its value is limited in the diagnosis of new cases of diabetes mellitus, due to an interindividual variation depending on multiple factors: age, gender, ethnicity, season (in the cold season the values are higher due to physiological and/or metabolic factors related to temperature), iron levels, smoking, erythrocyte turnover, glycation phenotype, etc.) and the difference between procedures (depending on the method used for the measurement, moreover, several error sources should be avoided). According to research data on Japanese diabetic patients, seasonal fluctuation of $\mathrm{HbA} 1 \mathrm{c}$ levels have been observed, with highest levels in March (7.69\%) and lowest in August (7.46\%; p<0.001) (1). Multiple factors seem to be involved in the seasonal variation of HbA1c: physical activity and food intake leading to weight changes (peaks were observed after holidays such as Christmas and Easter), exposure to sunlight (in correlation with vitamin D synthesis) depending on weather patterns. A study carried out in Greece showed significant differences between the highest HbA1c values (in March) and lowest (in September) (2). In a study performed on type 2 diabetic subjects with ages ranging between 26-94 years researchers concluded that serum vitamin D levels were inversely associated with HbA1c levels $(r=-0.116, p=0.003)$. This relation maintains its independence in the multivariate analysis after adjusting for age, sex, HbAlc, body mass index, treatment and duration of diabetes and nephropathy (3).

The value of HbAlc increases with age (4). The erythrocytes of patients with iron deficiency anemia have a longer lifetime, as such, they might have higher HbAlc values (5). Smoking increases $\mathrm{HbA} 1 \mathrm{c}$ value in type 1 and 2 diabetic patients (6). Teenage girls have significantly higher HbA1c values compared to boys of the same age (7). 
As hemodialysis increases the number of young erythrocytes as a consequence of the treatment with erythropoietin, the HbA1c values will be artefactually lower (8).

1. Each available HbAlc method has advantages and challenges, such as their susceptibility to interferences. The presence of $\mathrm{Hb}$ variants and/or abnormalities in $\mathrm{RBC}$ turnover can interfere not only analytically with $\mathrm{HbA1c}$ measurements, but may also affect the clinical interpretation of HbA1c values. Familiarity with the advantages and challenges of the various methods used for $\mathrm{HbA} 1 \mathrm{c}$ testing is essential when establishing therapeutic management and goals based on $\mathrm{HbA} 1 \mathrm{c}$ values, especially in populations with a high prevalence of $\mathrm{Hb}$ variants (9).

2. Current recommendations in clinical practice are that glycaemic targets should be individualized on the basis of the characteristics of each patient, considering age, co-morbidity and duration of diabetes $(10,11)$.

We studied and compared four chromatographic methods for HbAlc measurement, which included manual, semiautomatic, and automatic procedures.

Our purpose was to describe the advantages and disadvantages of the different methods, and to analyze the effect of some error sources on the $\mathrm{HbA} 1 \mathrm{c}$ results, revealing the problems that could occur in assays with less resolution. Additionally, we studied the correlation between the results obtained using the Variant I analyzer and those given by the Biomidi reagent kit, Micromat II and In2it.

\section{Material and methods}

\section{Equipments and sampling:}

We used the Variant I, Micromat II, In2it (Bio-Rad) analyzers, and a manual method using the Biomidi reagent kit. Blood samples were collected during November 2010 - March 2012 on $\mathrm{K}_{2}$ EDTA and stored at $2-8^{\circ} \mathrm{C}$. The majority of the patients $(71 \%)$ were admitted to the Diabetology Compartment of the Emergency County Clinical Hospital in Tîrgu Mures, others (29\%) were outpatients from the Marmed medical unit. The age of the patients was between $18-87$ years, $8 \%$ of them were type 1 diabetic subjects, the rest had type 2 diabetes. Many of them having been diagnosed over 5 years prior to our study.

2580 samples were analyzed using the Variant I equipment, 155 using the BIOMIDI kit and a StatFax photometer. 584 samples were analyzed using the semiautomatic Micromat II (BioRad) method at the Marmed Laboratory in Tîrgu Mureş, 465 samples were processed by the new generation of the Micromat II called In2it (automatic analyzer). The largest number of patient samples were processed on the Variant I, this analyzer being located in the Central Laboratory of the Emergency County Clinical Hospital in Tîrgu Mures.

We evaluated the advantages and disadvantages of these methods, the possible error sources working on samples from diabetic patients (effect of storage at different temperatures, presence of elevated $\mathrm{HbF}$ ) and Lyphochek control blood (effect of dilution), and the correlation of the results obtained using different methods. The measurements of the compared four equipment were made in different time ranges, so not the same samples had been processed on all the analyzers. Results obtained by the BIOMIDI kit and those on the small capacity point-of-care equipment (Micromat II and In2it) were compared to the reference method (HPLC) using the Variant I analyzer.

\section{Performance of the studied methods}

According to the data provided by the Instruction Manual of each equipment, we could compare the performance of the studied analyzers. The 
mentioned document reveals that the Micromat II has a precision of $4.65 \%$ using normal control values (mean: $5.2 \%$ ), and $2.93 \%$ using high control values (mean: $9.48 \%$ ). These results were obtained during 20 days by one operator using the same instrument and a single batch of reagents using the MicroSafe pipette included in the kit. The manual also mentions the fact that data generated by more than one operator, using multiple instruments and multiple lots of reagents, may have a higher coefficient of variation (CV). The Micromat II system gives a linear response between $4-15 \% \mathrm{HbA} 1 \mathrm{c}$ using patient samples, and the theoretical performance of the test indicates a linear range of 2 to $>25 \% \mathrm{HbA} 1 \mathrm{c}$ values (12).

According to the data provided by the manufacturer, the In2it analyzer showed a $\mathrm{CV}$ of $2.9 \%$ in case of normal $\mathrm{HbAlc}$ values (mean: $5.3 \%$ ), CV was $3.1 \%$ in case of slightly elevated HbA1c values (mean: $8.9 \%$ ), and it was $2.8 \%$ in case of very high $\mathrm{HbA1c}$ values (mean: $12.0 \%$ ) using three different batches of test cartridges (13).

Based on the data in the Instruction Manual, the Variant I system shows a better total precision compared to the previous two point-of-care analyzers, the $\mathrm{CV}$ is $2.08 \%$ for normal patient values, and $1.67 \%$ for diabetic values. Linearity is good up to HbA1c values of $17.9 \%$ (14).

Effect of improper sample dilution on the HbAlc value:

We studied the effect of improper sample dilution on the $\mathrm{HbA} 1 \mathrm{c}$ results using the Micromat II and Variant I analyzers, because the plastic pipetting devices of these equipment is predisposed to certain errors. In case of the automatic In2it analyzer, improper sample dilution is not an issue, because the hard plastic pipetting device aspirates the exact amount of required blood, the tip of the device is introduced directly into the cartridge.

In the case of Variant I, when pipetting the first few blood samples with the device, we
Table 1. Different dilutions of the control blood performed on the Variant I analyzer

\begin{tabular}{lll}
\hline Dilutions & $\begin{array}{l}\text { Blood } \\
\text { sample }(\boldsymbol{\mu l})\end{array}$ & $\begin{array}{l}\text { Hemolysis } \\
\text { reagent }(\boldsymbol{\mu l})\end{array}$ \\
\hline $1 / 100$ & 10 & 1000 \\
\hline $1 / 120$ & 9 & 1100 \\
\hline $1 / 140$ & 8 & 1100 \\
\hline $1 / 160$ & 7 & 1100 \\
\hline $1 / 180$ & 6 & 1100 \\
\hline $\mathbf{1 / 2 0 0}$ & $\mathbf{5}$ & $\mathbf{1 0 0 0}$ \\
\hline $1 / 220$ & 5 & 1100 \\
\hline $1 / 240$ & 5 & 1200 \\
\hline $1 / 260$ & 5 & 1300 \\
\hline $1 / 280$ & 5 & 1400 \\
\hline $1 / 300$ & 5 & 1500 \\
\hline $1 / 400$ & 5 & 2000 \\
\hline
\end{tabular}

observed that the aspirated volume was not the required $5 \mu \mathrm{l}$, which corresponds to the $1 / 200$ dilution with the $1000 \mu 1$ hemolysis reagent. It is important to know if these samples should be processed for the $\mathrm{HbAlc}$ measurement or the pipetting should be repeated for them. We studied the effect of improper dilutions (in the range between $1 / 100-1 / 400$ ) on the result of HbA1c measurement.

In case of the Micromat II analyzer, we tested the following improper blood volumes: $6,7,8$, 9, $11,12 \mu 1$.

Sample volume, storage and costs:

In the case of Variant I, the standard dilution of the blood collected on $\mathrm{K}_{2}$ EDTA is $1 / 200$. Five $\mu 1$ venous blood is required. Blood samples can be stored for up to 7 days at $2-8^{\circ} \mathrm{C}$. The cost of a test is around $22 \mathrm{RON}$.

For the BIOMIDI kit, a manual chromatographic method, $50 \mathrm{ml}$ of blood is required, absorbances are read at $415 \mathrm{~nm}$ at the photometer, the percentage of $\mathrm{HbAlc}$ is determined compared to total hemoglobin. 
Blood samples can be stored for up to 10 days at $2-8^{\circ} \mathrm{C}$. The cost of a test is around $18 \mathrm{RON}$.

In the case of Micromat II, the standard blood volume is $10 \mu \mathrm{l}$, a test cartridge is used and blood samples can be stored for up to 4 days at $2-8^{\circ} \mathrm{C}$. The cost of a test is around $28 \mathrm{RON}$.

The In2it analyzer is the automatized and further developed variant of Micromat $^{\mathrm{TM}}$ II. The principle is based on boronate affinity chromatography. Standard venous blood volume required is $10 \mu \mathrm{l}$, special pipetting devices are included in the kit. A test cartridge is used, and blood samples can be stored for up to 4 days at $2-8^{\circ} \mathrm{C}$. The cost of a test is around $30 \mathrm{RON}$.

Statistical analysis was performed by the GraphPad InStat program - Pearson correlation and data were processed using Microsoft Excel. The level of significance was set to p below 0.05 .

\section{Results}

Correlation between the results obtained by different methods:

Fifty-five samples were processed by the manual chromatographic method and by the Variant I analyzer. Thirty-nine of these samples (having elevated $\mathrm{HbF}$ ) were selected and processed also with the BIOMIDI reagent kit. We observed a good correlation between values obtained using the Variant I analyzer and the BIOMIDI reagent kit $(r=0.9654, p<0.05)$, except for some cases of elevated $\mathrm{HbF}$ (found in case of $2 \%$ of the studied population), because in case of the manual method, $\mathrm{HbF}$ and $\mathrm{HbAlb}$ fraction (where glycated $\mathrm{HbF}$ might be present) coelute with the $\mathrm{HbA} 1 \mathrm{c}$ fraction, leading to falsely elevated results (Figure 1).

In patients having elevated $\mathrm{HbF}$ values, the HbAlc results obtained on the BIOMIDI system were the sum of the percentages of the mentioned peaks on the Variant I analyzer (HbA1c+HbF+HbA1b).

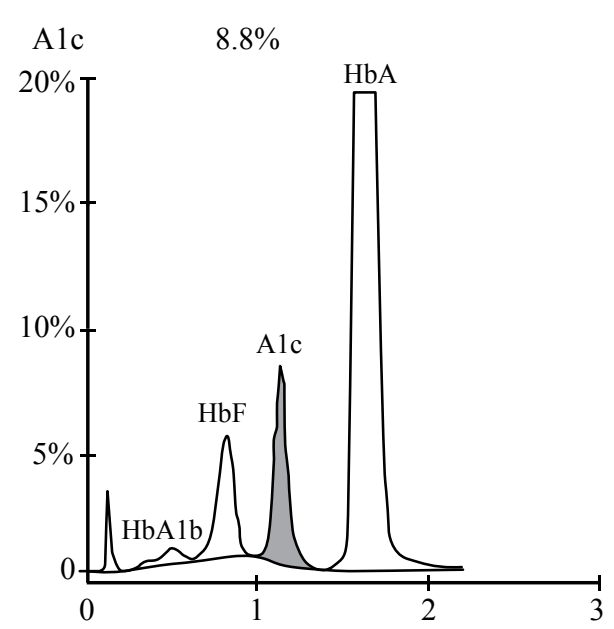

Figure 1. Variant I chromatogram of a diabetic patient presenting $8.8 \% \mathrm{HbA1c}$, elevated $\mathrm{HbF}(7.5 \%)$ and $\mathrm{HbA} 1 \mathrm{~b}(1.4 \%)$

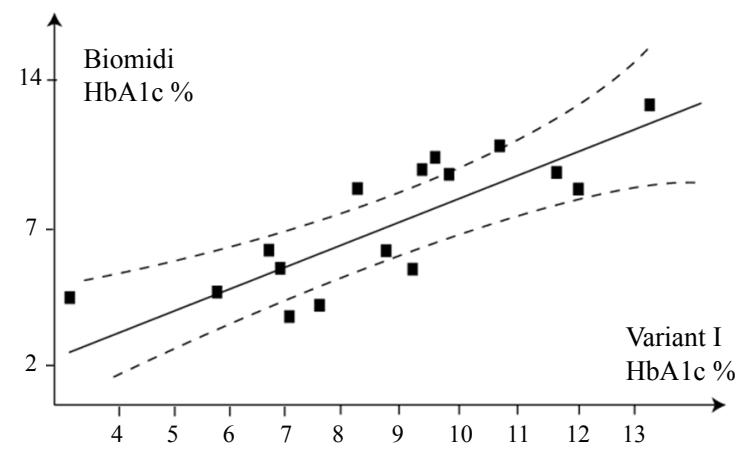

Figure 2. Correlation between HbA1c values (BIOMIDI, Variant I) of patients having normal $\mathrm{HbF}$ values (under $1 \%$ of total $\mathrm{Hb}$ )

In the 35 samples analyzed by the Micromat II analyzer and the Variant I method, we observed good correlation $(\mathrm{r}=0.9738, \mathrm{p}<0.05)$. We noted that the results obtained by Variant I were slightly higher, with an average of $0.52 \%$. This is clinically significant according to NACB guidelines.

We performed $\mathrm{HbA} 1 \mathrm{c}$ testing of 27 samples using the In2it and Variant I analyzers. Positive correlation of the results could be observed $(\mathrm{r}=0.9763, \mathrm{p}<0.05)$. 
Effect of improper sample dilution, incorrect storage and handling on the results of the HbAlc measurement

In case of Variant I, too intense shaking (prolonged and energetic shaking instead of mild homogenization) leads to degradation products forming separated peaks. Storage at $-20^{\circ} \mathrm{C}$ causes unknown peaks on the chromatogram, and the results are considerably lower than the real values. Storage at $-70^{\circ} \mathrm{C}$ caused hemolysis, but the blood was well-preserved, the obtained results were very close to the initial values (under $0.5 \%$ difference). In case of improper storage at room temperature for 24 $\mathrm{h}$, the measured $\mathrm{HbA} 1 \mathrm{c}$ results presented 3\% deviation from the actual values obtained using the Variant I analyzer.

The influence of improper sample dilution on the HbA1c results obtained can be observed in Table 2 (Variant I) and Table 3 (Micromat II).

The Micromat II analyzer displayed the "ERROR" message when using $12 \mu 1$ or more blood.

Table 2. Results of HbA1c measurement from control blood on Variant I using improper sample dilution

\begin{tabular}{llll}
\hline $\begin{array}{l}\text { Dilu- } \\
\text { tion }\end{array}$ & $\begin{array}{l}\text { HbA1c val- } \\
\text { ue }(\%)\end{array}$ & $\begin{array}{l}\text { Deviation } \\
\text { values }\end{array}$ & $\begin{array}{l}\text { Percent de- } \\
\text { viation }(\%)\end{array}$ \\
\hline $1 / 100$ & 13.5 & 0.7 & 4.929 \\
\hline $1 / 120$ & 13.8 & 0.4 & 2.817 \\
\hline $1 / 140$ & 14.0 & 0.2 & 1.408 \\
\hline $1 / 160$ & 14.2 & 0 & 0 \\
\hline $1 / 180$ & 14.6 & -0.4 & -2.817 \\
\hline $\mathbf{1 / 2 0 0}$ & $\mathbf{1 4 . 2}$ & - & - \\
\hline $1 / 220$ & 13.7 & 0.5 & 3.521 \\
\hline $1 / 240$ & 14.1 & 0.1 & 0.704 \\
\hline $1 / 260$ & 14.4 & -0.2 & -1.408 \\
\hline $1 / 280$ & 14.6 & -0.4 & -2.817 \\
\hline $1 / 300$ & 14.8 & -0.6 & -4.225 \\
\hline $1 / 400$ & 14.8 & -0.6 & -4.225 \\
\hline
\end{tabular}

Table 3. Blood sample volumes and correlated percent deviation from the target value on Micromat II

\begin{tabular}{ll}
\hline Sample volume $(\boldsymbol{\mu l})$ & $\begin{array}{l}\text { Percent deviation } \\
\text { from the target value }\end{array}$ \\
\hline 6 & $9.73 \%$ \\
\hline 7 & $6.74 \%$ \\
\hline 8 & $6.64 \%$ \\
\hline 9 & $3.34 \%$ \\
\hline 10 & - \\
\hline 11 & $-5.33 \%$ \\
\hline
\end{tabular}

In case of improper storage at room temperature for 24-h, the Micromat II equipment showed 5.3\% decrease in the $\mathrm{HbA} 1 \mathrm{c}$ results and $20 \%$ decrease after 48-h compared to the actual values.

The results of the HbAlc measurement presented $5.6 \%$ deviation from the actual values after $24 \mathrm{~h}$ at room temperature using the In 2 it analyzer, and $7.5 \%$ after $48 \mathrm{~h}$.

\section{Discussion}

Advantages and disadvantages of the methods:

\section{Variant system}

Variant I has the capacity of 100 samples/run, it also has Stat position for emergency samples, and requires 7-8 minutes/sample. Chromatographic cartridge, primer, calibrator, control blood are necessary, and an autodilutor is attached to the analyzer pipetting $5 \mu 1$ of blood. The preparation of the samples using the autodilutor system is time consuming for the operator, samples and controls are diluted to 1:200. A printer and a small screen are included in the analyzer, a series of buttons are used for settings; buffer 1, 2, wash and hemolysis/dilution solution are used.

\section{Small capacity equipment and methods}

At smaller sample number the automated chromatography analyzer In2it has several 
advantages compared to the semi-automatic Micromat II, but it has the disadvantage of frequent cartridge errors and higher cost. The In2it analyzer recognizes and rejects expired cartridges. Both systems can use capillary blood as sample.

Micromat II needs manual introduction of each solution, it is also rather expensive, but an advantage is that a calibrator cartridge is used, which has a long shelf life. The sample storage conditions and the precision of pipetting influence the results. The plastic pipetting device of Micromat II is predisposed to certain errors especially because of blood excess, while in the case of In 2 it the device has been improved, being more precise in pipetting $10 \mu \mathrm{l}$ blood. Micromat II has been gradually replaced by the In2it analyzer on the market.

The manual column chromatography assay using the Biomidi reagent kit is not accurate enough, the columns cannot sufficiently distinguish between the different forms of hemoglobin, and it requires long processing time ( 2 hours for a sample).

In $2 \%$ of the samples processed in Tîrgu Mureș we found persistent $\mathrm{HbF}$ (higher than $1.8 \%$ ) in non-pregnant patients. This might be the explanation for obtaining unexpectedly high $\mathrm{HbAlc}$ values in some cases using the manual chromatographic method, before the Variant I was available in this town.

We observed that in case of persistent $\mathrm{HbF}$, the $\mathrm{HbA} 1 \mathrm{~b}$ peak is also elevated, and these two fractions coelute with $\mathrm{HbAlc}$ in methods with less resolution than HPLC.

Some hemoglobin variants can coelute with the HbA1c fraction even on HPLC, for ex. $\mathrm{Hb}$ Camden or $\mathrm{Hb}$ Wayne, leading to falsely elevated HbA1c values (15).

In some cases (ex. in homozygous $\mathrm{HbE}$ ), the percentage of $\mathrm{HbA}$ can be so small that HbA1c does not appear on the chromatogram as a peak.
The accuracy of $\mathrm{HbAlc}$ measurement is very important in diabetic patients, therapeutic decision is made based on its value, and it is frequently used nowadays for the diagnosis of new cases. To evaluate $\mathrm{HbAlc}$ in populations with a high prevalence of hemoglobinopathies, we should use the HPLC method, which is easy to perform, economical, and reliable. Based on an algorithm, hemoglobin variants visualized on HPLC should be reported to the physician to improve the management of patients $(16,17)$.

A study comparing $23 \mathrm{HbA1c}$ assays sustains that $\mathrm{HbE}$ and $\mathrm{HbD}-\mathrm{Punjab}$ are the second and fourth most common $\mathrm{Hb}$ variants worldwide, thus, the scientists investigated the accuracy of $\mathrm{HbA} 1 \mathrm{c}$ measurement in the presence of $\mathrm{HbE}$ and/or HbD-Punjab traits. Of the evaluated $23 \mathrm{HbA} 1 \mathrm{c}$ measurement procedures, 9 were immunoassay methods, 10 were ionexchange HPLC methods, and 4 were capillary electrophoresis, affinity chromatography, or enzymatic methods. Statistically significant differences were found in more than half of the methods tested. Only $22 \%$ and $13 \%$ showed clinically significant interference for $\mathrm{HbE}$ and $\mathrm{HbD}$ traits, respectively. As a conclusion of this study, some current HbA1c methods show clinically significant interferences with samples containing $\mathrm{HbE}$ or $\mathrm{HbD}$ traits. To avoid reporting inaccurate results, ion-exchange chromatograms must be carefully examined to identify possible interference from these $\mathrm{Hb}$ variants (18).

Other point-of-care HbAlc measurement systems can be used in case of small number of samples, such as Nycocard Reader II, having very limited situations of error messages obtained especially in case of severe anemia. In case of larger sample numbers, photometric procedures are widely used nowadays instead of chromatographic procedures.

Our study presents some limitations. Some parameters of performance in case of the analyzers 
(precision, linearity) are presented based on information provided by the manufacturer. No data are available regarding comparison of the $\mathrm{HbA} 1 \mathrm{c}$ results obtained on all analyzers or on different point-of-care equipment, each of them only being compared to the best available HPLC analyzer in the area (Variant I), this being the reference method for this measurement. Outpatient samples were analyzed during different periods using the available equipment in the Marmed Laboratory.

\section{Conclusions}

The most appropriate methods for HbA1c testing are the automated chromatographic procedures because pipetting errors are minimized and do not require multiple stages of intervention from the laboratory personnel.

There is a positive correlation between the values obtained by different methods, except for the samples with elevated hemoglobin F.

Our study revealed that inappropriate handling or storage of the samples can lead to falsely higher or lower values of the HbAlc measurement.

\section{Conflict of interest}

The authors declare that there are no conflicts of interest.

\section{Abbreviations}

\begin{tabular}{|c|c|}
\hline $\mathrm{CV}$ & $=$ Coefficient of variation \\
\hline $\mathrm{HbA1c}$ & $=$ glycated hemoglobin \\
\hline HPLC & $\begin{array}{l}=\text { high pressure liquid } \\
\text { chromatography }\end{array}$ \\
\hline NACB & $\begin{aligned}= & \text { National Academy of Clinical } \\
& \text { Biochemistry }\end{aligned}$ \\
\hline
\end{tabular}

\section{References}

1. Sakura H, Tanaka Y, Iwamoto Y. Seasonal fluctuations of glycated hemoglobin levels in Japanese diabetic patients. Diabetes research and clinical practice, 2010;88(1):65-70. DOI: 10.1016/j.diabres.2009.12.011.

2. Gikas A, Sotiropoulos A, Pastromas V, Papazafiropoulou A, Apostolou O, Pappas S. Seasonal variation in fasting glucose and $\mathrm{HbAlc}$ in patients with type 2 diabetes. Primary Care Diabetes. 2009;3(2):111-4. DOI: 10.1016/j.pcd.2009.05.004.

3. Zoppini G, Galletti A, Targher G, Brangani C, Pichiri I, Negri C, et al. Glycated haemoglobin is inversely related to serum vitamin $\mathrm{D}$ levels in type 2 diabetic patients. Plos one, 2013;8(12):p.e82733 DOI: 10.1371/ journal.pone.0082733.

4. Pani LN, Korenda L, Meigs JB, Driver C, Chamany $\mathrm{S}$, Fox CS, et al. Effect of Aging on A1c Levels in Individuals Without Diabetes Evidence from the Framingham Offspring Study and the National Health and Nutrition Examination Survey 2001-2004. Diabetes Care. 2008;31(10):1991-6. DOI: 10.2337/ dc08-0577.

5. Coban E, Ozdogan M, Timuragaoglu A. Effect of iron deficiency anemia on the levels of hemoglobin A1c in nondiabetic patients. Acta haematol. 2004;112(3):1268. DOI: $10.1159 / 000079722$.

6. Nilsson, PM, Gudbjornsdottir S, Eliasson B, Cederholm J. Steering Comité of Swedish Nacional Diabetes Register. Smoking is associated with increased $\mathrm{HbAlc}$ values and microalbuminuria in patients with diabetesdata from National Diabetes Register in Sweden. Diabetes Metab. 2004;30:261-8. DOI: 10.1016/S12623636(07)70117-9.

7. Hanberger L, Åkesson K, Samuelsson U. Glycated haemoglobin variations in paediatric type 1 diabetes: the impact of season, gender and age. Acta Paediatr. 2014;103(4):398-403. DOI: 10.1111/apa.12530.

8. Hill CJ, Maxwell AP, Cardwell CR, Freedman BI, Tonelli M, Emoto M, et al. Glycated hemoglobin and risk of death in diabetic patients treated with hemodialysis: a meta-analysis. Am J Kidney Dis. 2014;63(1):84-94. DOI: 10.1053/j.ajkd.2013.06.020.

9. Rhea JM, Molinaro R. Pathology consultation on $\mathrm{HbA}(1 \mathrm{c})$ methods and interferences. Am J Clin Pathol. 2014;141(1):5-16. DOI: 10.1309/ AJCPQ23GTTMLAEVL. 
10. Monami M, Vitale V, Lamanna C, Bartoli N, Martelli D, Zannoni S, et al. HbA1c levels and all-cause mortality in type 2 diabetic patients: epidemiological evidence of the need for personalised therapeutic targets. Nutr Metab Cardiovasc Dis. 2012;23(4):300-6. DOI: 10.1016/j.numecd.2012.01.003.

11. Onitilo AA, Stankowski RV, Berg RL, Engel JM, Glurich I, Williams GM et al. Type 2 diabetes mellitus, glycemic control, and cancer risk. Eur J Cancer Prev. 2014;23(2):134-40. DOI: 10.1097/ CEJ.0b013e3283656394.

12. Bio-Rad. Instruction Manual Micromat II Hemoglobin A1c Test. 2004.

13. Bio-Rad. Instruction Manual In2it System A1c Test Cartridges. 2010.

14. Bio-Rad. Instruction Manual Variant Hemoglobin A1c Program. 2005.
15. Little RR, Roberts W. A Review of Variant Hemoglobins Interfering with Hemoglobin A1c Measurement. J Diabetes Sci Technol. 2009;3(3):446-51. DOI: 10.1177/193229680900300307.

16. Bouzid K, Ahmed HB, Kalai E, Blibeche S, Couque N, Chiari K, et al. Prevalence of hemoglobin variants in a diabetic population at high risk of hemoglobinopathies and optimization of $\mathrm{HbA} 1 \mathrm{c}$ monitoring by incorporating HPLC in the laboratory workup. Lybian J Med. 2014;27(9):257-68. DOI: 10.3402/ljm.v9.25768.

17. Higgins T: HbA1c - an analyte of increasing importance. Clin Biochem. 2012;45(13-14):1038-45. DOI: 10.1016/j.clinbiochem.2012.06.006.

18. Little RR, Rohlfing CL, Hanson S, Connolly S, Higgins $\mathrm{T}$, Weykamp CW, et al: Effects of hemoglobin $(\mathrm{Hb})$ $\mathrm{E}$ and $\mathrm{HbD}$ traits on measurements of glycated $\mathrm{Hb}$ (HbA1c) by 23 methods, Clin Chem. 2008;54(8):127782. DOI: $10.1373 /$ clinchem.2008.103580. 